\title{
Very Low Density Lipoproteins Stimulate Surfactant Lipid Synthesis In Vitro
}

\author{
Rama K. Mallampalli, ${ }^{\star \ddagger}$ Ronald G. Salome, ${ }^{\star \ddagger}$ Susan L. Bowen, ${ }^{\star \ddagger}$ and David A. Chappell ${ }^{\star \ddagger}$ \\ $*$ Department of Internal Medicine; and ${ }^{\ddagger}$ Department of Veterans Affairs Medical Center, The University of Iowa College of Medicine, \\ Iowa City, Iowa 52242
}

\begin{abstract}
Surfactant synthesis is critically dependent on the availability of fatty acids. One fatty acid source may be circulating triglycerides that are transported in VLDL, and hydrolyzed to free fatty acids by lipoprotein lipase (LPL). To evaluate this hypothesis, we incubated immortalized or primary rat alveolar pre-type II epithelial cells with VLDL. The cells were observed to surface bind, internalize, and degrade VLDL, a process that was induced by exogenous LPL. LPL induction of lipoprotein uptake significantly increased the rates of choline incorporation into phosphatidylcholine (PC) and disaturated PC, and these effects were associated with a threefold increase in the activity of the rate-regulatory enzyme for PC synthesis, cytidylyltransferase. Compared with native LPL, a fusion protein of glutathione $S$-transferase with the catalytically inactive carboxy-terminal domain of LPL did not activate CT despite inducing VLDL uptake. A variant of the fusion protein of glutathione $S$-transferase with the catalytically inactive carboxy-terminal domain of LPL that partially blocked LPL-induced catabolism of VLDL via LDL receptors also partially blocked the induction of surfactant synthesis by VLDL. Taken together, these observations suggest that both the lipolytic actions of LPL and LPL-induced VLDL catabolism via lipoprotein receptors might play an integral role in providing the fatty acid substrates used in surfactant phospholipid synthesis. (J. Clin. Invest. 1997. 99: 2020-2029.) Key words: lipoproteins • lipoprotein lipase • surfactant $\bullet$ triglycerides $\bullet$ nucleotidyltransferases
\end{abstract}

\section{Introduction}

Lung surfactant is a surface tension lowering mixture of lipids and hydrophobic proteins that lines the alveolar surface and maintains alveolar patency (1). Deficiency of surfactant is typically observed in the neonatal respiratory distress syndrome. In addition, a functional surfactant deficiency appears to be a pathogenic feature in a variety of acute and chronic adult lung disorders (2-5). Disaturated phosphatidylcholine (DSPC) $)^{1}$, the major lipid component of surfactant that lowers alveolar surface tension, is synthesized by alveolar type II epithelial cells

Address correspondence to Rama K. Mallampalli, Pulmonary Division, Department of Internal Medicine, University of Iowa College of Medicine, Iowa City, IA 52242. Phone: 319-356-1265; FAX: 319-3536406.

Received for publication 29 October 1996 and accepted in revised form 10 February 1997.

The Journal of Clinical Investigation

Volume 99, Number 8, April 1997, 2020-2029
(1). To maximally synthesize DSPC, these cells require adequate amounts of glucose, which serves as a source for the glycerol backbone of phosphatidylcholine (PC). In addition, DSPC synthesis requires long chain fatty acids that are derived from de novo synthesis, or uptake of free fatty acids either complexed to albumin, or possibly derived from triglycerides, in circulating lipoproteins (6).

VLDL are large, triglyceride-rich particles (30-100 nm) that are synthesized in the liver. Chylomicrons, which are somewhat larger than VLDL, are triglyceride-rich particles produced by the intestine. The clearance of VLDL- or chylomicron-triglyceride fatty acids from the microcirculation is regulated by a 101-kD serine hydrolase, lipoprotein lipase (LPL), which is anchored to endothelial and other cell surfaces by proteoglycans. LPL reacts with long chain triglycerides generating monoacylglycerols and unesterified fatty acids (7). There is evidence that in the presence of LPL, VLDL clearance is receptor mediated, since a variety of proteins, including the low density lipoprotein receptor, the LDL receptor-related protein (LRP), VLDL receptor, and glycoprotein 330 (gp330), which is also called megalin or LRP-2, all appear to bind and participate in the cellular internalization of these triglyceriderich particles (8-13). The role of gp330 may be of special relevance to VLDL metabolism in the lung since this receptor has been identified on the microvillus border of alveolar type II epithelial cells and in the immortalized pre-type II epithelial cells used in the current studies $(14,15)$. Solid-phase cell-free binding assays have demonstrated that LPL-VLDL complexes serve as ligands for gp330 (16). Catabolism of LPL-VLDL complexes is also modulated by receptor-associated protein (RAP), an antagonist for all known ligands that bind to the LDL receptors, VLDL receptor, LRP, or gp330 $(8,10)$.

There is evidence that VLDL may provide the free fatty acid substrate required for surfactant $\mathrm{PC}$ synthesis, although to date this hypothesis has not been directly tested. For example, prior studies reveal that the pulmonary vascular bed is exposed to high levels of circulating plasma triglycerides $(17,18)$. Other investigations using the isolated perfused rat lung system have demonstrated that the lung is actively involved in the catabolism of triglycerides in VLDL (19-22). Further, in vivo and in vitro studies indicate that rat lung expresses high levels of LPL activity $(18,21,22)$. This activity is detected primarily in lipid interstitial cells and alveolar macrophages (23-25). In related studies, Torday et al. (26) recently reported that fetal

1. Abbreviations used in this paper: $\alpha_{2} \mathrm{M}^{*}$, LRP-binding form of alpha-2-macroglobulin; CT, cytidylyltransferase; DSPC, disaturated PC; GST, glutathione $S$-transferase; GST-LPLC, a fusion protein of GST with the catalytically inactive carboxy-terminal domain of LPL; LPDS, lipoprotein-deficient serum; LPL, lipoprotein lipase; LRP, LDL receptor-related protein; PC, phosphatidylcholine; RAP, receptor-associated protein. 
alveolar type II epithelial cells, unlike fetal lung fibroblasts, were unable to incorporate $\left[{ }^{3} \mathrm{H}\right]$ triacylglycerol directly from serum-containing culture medium into DSPC. However, when fetal lung fibroblasts were preloaded with $\left[{ }^{3} \mathrm{H}\right]$ triacylglycerol and recombined in culture with fetal type II cells, a significant increase in DSPC synthesis was detected in the fetal type II cells (26). These results suggest that fibroblasts could serve as a reservoir for triglycerides destined for surfactant synthesis in alveolar type II epithelial cells.

We hypothesize that triglyceride-rich lipoproteins, VLDL and chylomicrons, stimulate surfactant synthesis by direct interaction with alveolar pre-type II epithelial cells. There are at least two mechanisms whereby VLDL or chylomicrons could supply fatty acids for surfactant production. In the first, lipoproteins would undergo lipolysis by LPL attached to cell surface proteoglycans on pulmonary endothelium, and the released fatty acids would gain access to the pre-type II cells by diffusion. Such a mechanism would be consistent with data provided by Torday et al. (26) and others. In a second mechanism, VLDL, chylomicrons, or their lipolytic remnants would penetrate the endothelial barrier, allowing the LPL-VLDL complexes to interact directly with lipoprotein receptors on pre-type II cells including LDL receptors, LRP, and gp330 as described above. It is known that free fatty acids released during lipolysis increase endothelial permeability in vitro (27). Recently, it has been demonstrated that intact VLDL particles and their remnants may penetrate the aortic endothelial barrier, suggesting that VLDL may also penetrate the pulmonary endothelium $(28,29)$. In addition, LPL, which is produced by alveolar macrophages, is present in normal bronchoalveolar lavage fluid, where it may facilitate the cellular uptake of lipids derived from surfactant or lipoproteins (30). In the absence of normal LPL activity, as occurs in cld/cld mice, large triglyceride-rich lipoproteins may actually be seen within the alveolar lumen (31).

In the present study, we demonstrate that VLDL are surface bound and internalized by immortalized or primary rat alveolar pre-type II epithelial cells. The lipoproteins stimulate surfactant production in these cells by activating the rate-limiting enzyme required for PC synthesis, CTP:phosphocholine cytidylyltransferase (CT) (E.C. 2.7.7.15) (32).

\section{Methods}

Materials. Lipoproteins were obtained from fasted normolipemic human subjects, all of whom had the most common apoE phenotype $(\mathrm{E} 3 / 3)$ as determined by isoelectric focusing gel electrophoresis (8). Intermediate size VLDL with $\mathrm{S}_{f} 60-100$ (from the $d<1.006 \mathrm{~g} / \mathrm{ml}$ fraction of plasma) and lipoprotein-deficient serum (LPDS, $d>1.21 \mathrm{~g} / \mathrm{ml}$ ) were isolated by ultracentrifugation (9). In some early experiments, large VLDL with $\mathrm{S}_{f} 100-400$ were used. Because large and intermediate VLDL gave similiar results, the data were combined. Low density lipoproteins with $d=1.02-1.05 \mathrm{~g} / \mathrm{ml}$ were used in some studies for comparison with VLDL and were obtained from the same subjects using previously described methods $(8,9)$. Radiolabeled lipoproteins were prepared as reported (8). Lipoproteins were stored at $4^{\circ} \mathrm{C}$ and used within $6 \mathrm{wk}$ after isolation. The lovastatin was a gift from Merck, Sharp, and Dome Research Labs (Rahway, NJ). Bovine milk LPL was isolated as described previously (33). RAP was prepared using a bacterial expression system (8). The carboxyl-terminal portion of human LPL (amino acid residues 313-348), termed LPLC, was generated as a fusion protein with glutathione $S$-transferase (GST) in Escherichia coli (11). The tryptophan residues at positions 393 and 394 of LPL were changed to alanine using site-directed mutagenesis to generate GST-LPLCww (11). Human alpha-2-macroglobulin $\left(\alpha_{2} \mathrm{M}\right)$ was provided by Dudley K. Strickland (American Red Cross, Rockville, $\mathrm{MD}$ ) and activated by treatment with methylamine as previously described (8) to produce the LRP-binding form of the protein $\left(\alpha_{2} \mathrm{M}^{*}\right)$. Bovine serum albumin ( $>99 \%$ fatty acid free) was obtained from Miles Inc. (Kankakee, IL). Waymouth's MB 752/1 medium was obtained from the University of Iowa Tissue Culture and Hybridoma Facility (Iowa City, IA). The phospholipid standards, phosphocholine and CTP, were purchased from Sigma Chemical Co. (St. Louis, MO). All solvents were of Optima grade (Fisher Chemical Co., Fair Lawn, NJ). Silica LK5D $(250 \mathrm{~mm} \times 20 \mathrm{~cm} \times 20 \mathrm{~cm})$ chromatography plates were purchased from Whatman International (Maidstone, UK). Chemiluminescence reagents for immunodetection of CT were purchased from Amersham Corp. (Arlington Heights, IL). Radiochemicals including [methyl ${ }^{-3} \mathrm{H}$ ]choline chloride $(86.6 \mathrm{Ci} / \mathrm{mmol})$ and the $\left[\right.$ methyl $\left.{ }^{-14} \mathrm{C}\right]$ phosphocholine $(50 \mathrm{mCi} / \mathrm{mmol})$ were obtained from DuPont-NEN (Boston, MA). The $\left[{ }^{3} \mathrm{H}\right]$ water $(5 \mathrm{Ci} / \mathrm{ml})$ was obtained from ICN Pharmaceuticals Inc. (Costa Mesa, CA). Antibody to a synthetic peptide from the cytidylyltransferase sequence was generously provided by Dr. Dennis Vance (University of Alberta, Edmonton, Canada) (34).

Cell culture. Immortalized rat fetal alveolar pre-type II epithelial cells were generated by infection with a retroviral construct expressing the adenoviral 12S E1A gene product (35). The features of these cells, including abundant glycogen stores, absence of lamellar bodies, and lectin binding, which are typical characteristics of alveolar pretype II epithelial cells in primary culture, have been described (35). In the current studies, we used cells that have undergone $\sim 110$ passages. Cells were maintained in Waymouth's $752 / 1$ medium with $10 \%$ fetal calf serum at $37^{\circ} \mathrm{C}$ in atmosphere containing $5 \% \mathrm{CO}_{2}$. After reaching confluence, the cells were harvested using $0.25 \%$ trypsin with $0.1 \%$ EDTA and plated onto 35-mm tissue culture dishes $(\sim 175,000$ cells/dish). After incubation overnight, the media was removed and the cells rinsed twice with medium containing $0.1 \%$ fatty acid free albumin, and then incubated with medium containing either $10 \%$ FCS, or LPDS $(2 \mathrm{mg} / \mathrm{ml})$. After a 48 -h incubation, the cells were incubated further under similar conditions, or exposed to medium with LPDS in the presence of VLDL $(30 \mu \mathrm{g} / \mathrm{ml})$, lipoprotein lipase $(0.5 \mu \mathrm{g} / \mathrm{ml})$, or VLDL $(30 \mu \mathrm{g} / \mathrm{ml})$ plus LPL $(0.5 \mu \mathrm{g} / \mathrm{ml})$ for various time periods. The LPL was added during the last $2 \mathrm{~h}$ of the incubation. For comparison, we also performed studies in freshly isolated (day 19 gestation) rat fetal pre-type II cells (36). After isolation, these cells were plated and cultured under similar experimental conditions as described above.

Subcellular preparations. After incubation of cells under the conditions above, the media was removed and the cells rinsed twice with cold phosphate-buffered saline $\left(4^{\circ} \mathrm{C}\right)$ containing $0.1 \%$ fatty acid free albumin. The cells were scraped from the dishes using a Teflon ${ }^{\circledR}$ cell scraper, centrifuged to isolate a cell pellet, and resuspended in buffer before sonication as described previously (37). The cytosolic and microsomal cellular fractions were then isolated as described (37). Some preparations were stored under nitrogen gas at $-80^{\circ} \mathrm{C}$ for enzyme and lipid analysis.

Cell-surface binding, internalization, and degradation of lipoproteins. The cellular catabolism of lipoproteins was determined as described previously (8). Briefly, cells were plated on $25-\mathrm{mm}$ plastic wells at a density of $2.5 \times 10^{4} \mathrm{cells} / \mathrm{ml}$ and incubated at $37^{\circ} \mathrm{C}$ in Waymouth's $752 / 1$ medium containing $10 \%$ fetal bovine serum. The cells were grown to confluence in $6 \mathrm{~d}$. In some studies, LDL receptors were downregulated for $24 \mathrm{~h}$ before the assay with medium containing $20 \mu \mathrm{g} / \mathrm{ml}$ of LDL, or upregulated for $48 \mathrm{~h}$ with medium containing $2 \mathrm{mg} / \mathrm{ml}$ LPDS with $1 \mu \mathrm{g} / \mathrm{ml}$ lovastatin in the medium for the final $24 \mathrm{~h}$. Steady state levels of ${ }^{125}$ I-VLDL surface binding, internalization, and degradation were determined after incubating cells with radiolabeled ligands and various amounts of $\mathrm{LPL}$ for $5 \mathrm{~h}$ at $37^{\circ} \mathrm{C} \mathrm{(8)}$. Surface-binding and internalization were defined as radioactivity that was released or remained cell associated, respectively, after a brief incubation of cells at $4^{\circ} \mathrm{C}$ in buffer containing $10 \mathrm{mg} / \mathrm{ml}$ of tripolyphosphate. Degradation was defined as the trichloroacetic acid-soluble radioactivity in 
the incubation medium. In some studies, cellular catabolism was evaluated using the LDL receptor antagonist RAP. As an indicator of LRP activity, cellular catabolism of ${ }^{125} \mathrm{I}-\alpha_{2} \mathrm{M}^{*}$ was assessed $(8,10)$.

De novo synthesis of fatty acids and phosphatidylcholine. Cells were cultured as described above in Waymouth's 752/1 medium containing either $10 \%$ fetal calf serum or $2 \mathrm{mg} / \mathrm{ml}$ LPDS. After an initial incubation period, the cells were incubated again under similar conditions, or with the addition of VLDL $(30 \mu \mathrm{g} / \mathrm{ml})$, LPL $(0.5 \mu \mathrm{g} / \mathrm{ml})$, or VLDL $(30 \mu \mathrm{g} / \mathrm{ml})$ plus LPL $(0.5 \mu \mathrm{g} / \mathrm{ml})$ for 4 or $24 \mathrm{~h}$. The cells were then pulsed with either $5 \mathrm{mCi} /$ dish of $\left[{ }^{3} \mathrm{H}\right]$ water, or $2 \mu \mathrm{Ci}$ of [methyl$\left.{ }^{3} \mathrm{H}\right]$ choline chloride for the final $4 \mathrm{~h}$ of incubation. After labeling, the medium was removed and the cells were rinsed, scraped, and sonicated as described above. Total fatty acids were extracted and saponified in $4 \% \mathrm{KOH}$ in $90 \%$ methanol for $2 \mathrm{~h}$ at $85^{\circ} \mathrm{C}$. The fatty acids were acidified and extracted in hexane as described (38). After removing excess acid, the fatty acid residue was applied to silica LK5D plates and developed in hexane:ethyl ether-formic acid (160:40:4, vol/ $\mathrm{vol} / \mathrm{vol}$ ) (38). After the plates were dried and fatty acid standards visualized, samples with corresponding $R_{\mathrm{f}}$ were scraped from the silica gel and placed directly in counting vials for scintillation counting. Phospholipids were extracted from equal amounts of cellular protein using the method of Bligh and Dyer (39). The lipids were dried and resolved using thin layer chromatography as described (40). Samples that comigrated with PC standard were scraped from the silica gel and directly counted. The levels of DSPC were determined using osmium tetroxide (40).

Cytidylyltransferase assay. The activity of CT was determined by measuring the rate of incorporation of [methyl- $\left.{ }^{14} \mathrm{C}\right]$ phosphocholine into CDP-choline using a charcoal extraction method $(37,38)$. Each reaction mixture consisted of $1.6 \mathrm{mM}\left[\right.$ methyl $\left.-{ }^{14} \mathrm{C}\right]$ phosphocholine, $3.0 \mathrm{mM}$ CTP, $12 \mathrm{mM} \mathrm{Mg}$ acetate, $50 \mathrm{mM}$ imidazole, $150 \mathrm{mM} \mathrm{KCl}$, and $2 \mathrm{mM}$ EDTA, $\mathrm{pH}$ 7.0. In a total assay volume of $100 \mu$, the reaction was initiated by the addition of $20 \mu \mathrm{l}(\sim 45 \mu \mathrm{g})$ of cellular protein at $37^{\circ} \mathrm{C}$, and terminated after $1 \mathrm{~h}$ by the addition of $10 \%$ trichloroacetic acid. The reaction was linear with respect to time and the amount of enzyme protein added to the assay mixture. The recovery of the product, CDP-choline, was $\sim 71 \%$. Unless stated otherwise, all assays were performed without the inclusion of a lipid activator in the reaction mixture.

Immunodetection of $C T$. Proteins were quantitated using the Bradford assay (41). Total cellular protein extracts were loaded and separated on $10 \%$ SDS-PAGE (300-400 $\mu \mathrm{g} / \mathrm{lane})$. The separated proteins were transferred from the gel to a nitrocellulose membrane at $4^{\circ} \mathrm{C}$ over 5-7 h (37). The membranes were then blocked for $2 \mathrm{~h}$ in Blotto at $25^{\circ} \mathrm{C}$, and subsequently exposed to rabbit anti-CT peptide (1:500) overnight. The membranes were rinsed $4 \times$ in Blotto and exposed to goat anti-rabbit horseradish peroxidase antibody (1:600) for $1 \mathrm{~h}$. The membrane was washed twice in Blotto, twice in Tween-20 TBS, and twice in tris-buffered saline for $10 \mathrm{~min}$ each. The membrane was then exposed to the chemiluminescence reagents for $1 \mathrm{~min}$ and exposed to autoradiographic film $(40 \mathrm{~min})$ to detect immunoreactive proteins.
Statistical analysis. The data are expressed as the mean \pm SEM. Statistical analysis was performed using the one-way ANOVA with the Bonferroni adjustment for multiple comparisons (42).

\section{Results}

Cell-surface binding, internalization, and degradation of lipoproteins. In the basal state, immortalized pre-type II epithelial cells bound, took up, and degraded native ${ }^{125}$ I-labeled human VLDL and LDL. VLDL catabolism was markedly induced by the addition of LPL as expected based on our previous results with fibroblasts, chinese hamster ovary cells, and human umbilical vein endothelial cells $(8,12,13)$. As shown in Fig. 1, the cells exhibited a nearly fourfold increase in steady state degradation of ${ }^{125} \mathrm{I}$-labeled VLDL ligand in the presence of increasing amounts of exogenous LPL in the culture medium. On average, LPL at $0.3 \mu \mathrm{g} / \mathrm{ml}$ increased VLDL degradation $3.3 \pm 0.4-$ fold in three separate experiments. In contrast to ${ }^{125}$ I-labeled VLDL catabolism, little catabolism of LDL was detected in the absence of LPL, consistent with previous evidence that human LDL binds poorly to rat LDL receptors (43). Likewise, LPL did not stimulate degradation of ${ }^{125}$ I-labeled LDL as much as it stimulated ${ }^{125}$ I-labeled VLDL degradation consistent with the fact that VLDL are better substrates for LPL. In other studies (not shown), the concentration of LPL was fixed at $0.3 \mu \mathrm{g} / \mathrm{ml}$ as ${ }^{125}$ I-labeled VLDL concentrations were increased. In the presence of $0.3 \mu \mathrm{g} / \mathrm{ml}$, LPL degradation was shown to be saturated above an ${ }^{125}$ I-labeled VLDL concentration of $\sim 7 \mathrm{nM}$.

To determine the contribution of LDL receptors to lipoprotein catabolism by pre-type II cells, we performed several experiments in which catabolism in the absence of LDL receptor upregulation was compared with catabolism during culture in cholesterol-free medium (Fig. $2 A$ ). Upregulation of LDL receptors by culturing cells in cholesterol-free medium resulted in a $1.6 \pm 0.2$-fold increase in LPL-induced ${ }^{125}$ I-labeled VLDL degradation (Fig. $2 A$ ) and a 3.1 \pm 0.9 -fold increase in ${ }^{125}$ I-labeled LDL degradation in three separate experiments (data not shown). Similar results were seen for surface binding and uptake of lipoproteins (data not shown). As previously observed in other cell lines, enzymatic activity of LPL was not required for induction of catabolism under either culture condition (Fig. $2 A$ ) (11-13). A fusion protein of GST with the catalytically inactive carboxy-terminal domain of LPL (GSTLPLC) markedly induced catabolism of ${ }^{125} \mathrm{I}$-labeled VLDL, but required $\sim 100$-fold higher concentrations consistent with previous results (11-13) (Fig. $2 A$ ). Incubation with GST alone had no effect (Fig. $2 C$ ).
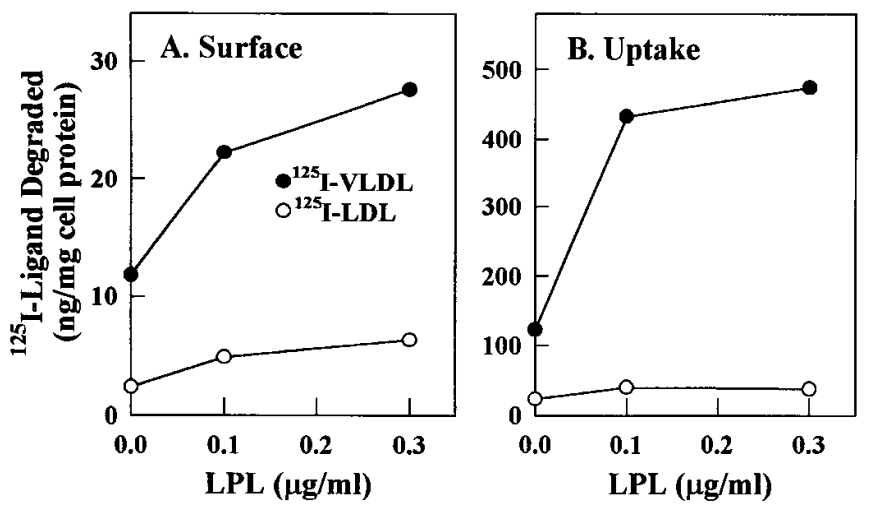

Figure 1. LPL-induced catabolism of VLDL by immortalized alveolar pre-type II epithelial cells. Confluent cells on $35-\mathrm{mm}$ plastic wells were incubated at $37^{\circ} \mathrm{C}$ in Waymouth's medium containing $10 \%$ fetal bovine serum. Cells were incubated with $3.5 \mathrm{nM}^{125} \mathrm{I}-\mathrm{VLDL}(\bullet)$ or ${ }^{125} \mathrm{I}-\mathrm{LDL}(\mathrm{O})$ in the presence of various amounts of LPL for $5 \mathrm{~h}$ at $37^{\circ} \mathrm{C}$. Steady state levels of ligand surface binding $(A)$, internalization $(B)$, and degradation $(C)$ in duplicate were determined as described in Methods. 

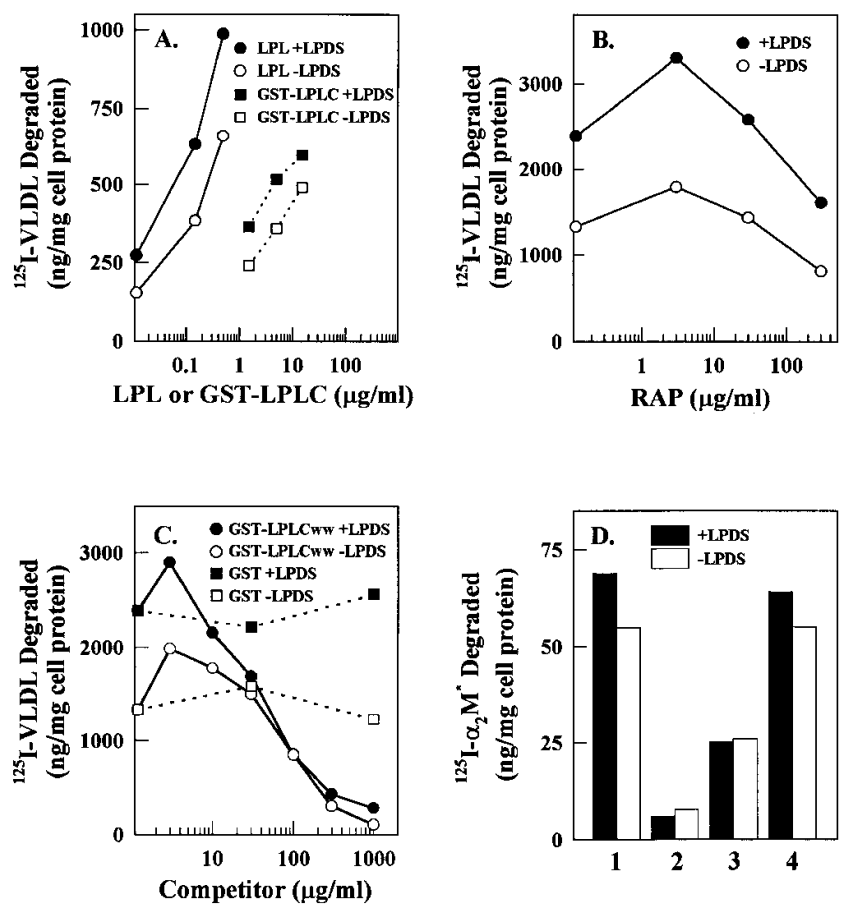

Figure 2. Effect of inhibitors of LPL-induced catabolism of VLDL or $\alpha_{2} \mathrm{M}^{*}$ by immortalized alveolar pre-type II epithelial cells. Confluent cells on $35-\mathrm{mm}$ plastic wells were incubated at $37^{\circ} \mathrm{C}$ in Waymouth's medium containing either $10 \%$ fetal bovine serum (open symbols) or $2 \mathrm{mg} / \mathrm{ml}$ of lipoprotein-deficient serum (closed symbols) as described in Methods. $(A)$ Cells were incubated with $3.5 \mathrm{nM}^{125} \mathrm{I}-\mathrm{VLDL}$ in the presence of various amounts of LPL or GST-LPLC for $5 \mathrm{~h}$ at $37^{\circ} \mathrm{C}$. (B) Cells were incubated with $0.1 \mu \mathrm{g} / \mathrm{ml}$ of LPL and $3.5 \mathrm{nM}$ ${ }^{125} \mathrm{I}-\mathrm{VLDL}$ in the presence of various amounts of RAP. (C) Cells were incubated with $0.1 \mu \mathrm{g} / \mathrm{ml}$ of LPL and $3.5 \mathrm{nM}^{125} \mathrm{I}-\mathrm{VLDL}$ in the presence of various amounts of GST-LPLCww (circles) or GST (squares) as indicated for $5 \mathrm{~h}$ at $37^{\circ} \mathrm{C} .(D)$ Cells were incubated under similar conditions using $1.4 \mathrm{nM}^{125}$ I-labeled activated $\alpha_{2} \mathrm{M}^{*}$ alone (lane 1), or in combination with RAP $(30 \mu \mathrm{g} / \mathrm{ml})$, (lane 2), GSTLPLCww $(50 \mu \mathrm{g} / \mathrm{ml})$ (lane 3), or GST (50 $\mu \mathrm{g} / \mathrm{ml})$ (lane 4). Steady state levels of ligand degradation in duplicate were determined as described in Methods.

In the absence and presence of LDL-receptor upregulation, we were able to inhibit LPL-induced catabolism of ${ }^{125}$ I-labeled VLDL using two previously described inhibitors of the LDL receptor and LRP pathways, RAP (Fig. $2 \mathrm{~B}$ ), or a variant of GST-LPLC in which tryptophans at residues 393 and 394 were changed to alanine (GST-LPLCww) (Fig. 2 C). GST-LPLCww can no longer bind to lipoproteins, but retains the ability to bind cell surface proteoglycans, LDL receptors, and LRP (11-13). As a result, it is a potent antagonist of receptor-mediated clearance via these receptors; the effective concentration for $50 \%$ inhibition of LPL-induced catabolism was $72 \pm 12$ and $85 \pm 45 \mathrm{mg} / \mathrm{ml}$ in the presence or absence of LPDS, respectively $(n=4)$. In contrast with GST-LPLCww, inhibition of LPL-induced ${ }^{125}$ I-labeled VLDL catabolism by RAP (Fig. $2 \mathrm{~B}$ ) was only partial in the presence or absence of LPDS with $33-69 \%$ inhibition $(n=4)$ at the highest concentration of RAP tested $(300 \mu \mathrm{g} / \mathrm{ml})$. Data in Fig. $2 D$ indicate that ${ }^{125} \mathrm{I}-\alpha_{2} \mathrm{M}^{*}$ catabolism by type II cells is also inhibited by RAP and GSTLPLCww, as expected from studies in other cell lines $(8,10$

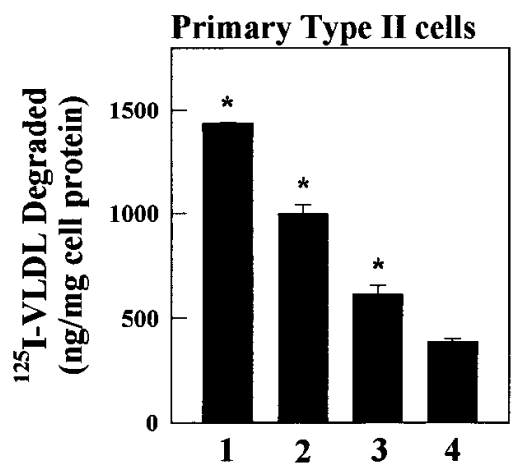

Figure 3. LPL-induced catabolism of VLDL by primary isolates of alveolar pre-type II epithelial cells. Confluent cells on 35-mm plastic wells were incubated at $37^{\circ} \mathrm{C}$ in Waymouth's medium containing LPDS $(2 \mathrm{mg} / \mathrm{ml})$ for $5 \mathrm{~h}$ at $37^{\circ} \mathrm{C}$. Steady state levels of ligand degradation in triplicate were determined as de-

scribed in Methods. Cells were incubated with $3.5 \mathrm{nM}{ }^{125} \mathrm{I}-\mathrm{VLDL}$ alone (lane 4), or ${ }^{125} \mathrm{I}-\mathrm{VLDL}$ in combination with (lane 1$) 0.3 \mu \mathrm{g} / \mathrm{ml}$ of LPL, (lane 2) LPL $(0.3 \mu \mathrm{g} / \mathrm{ml})$ plus RAP $(300 \mu \mathrm{g} / \mathrm{ml})$, or (lane 3) GST-LPLC $(30 \mu \mathrm{g} / \mathrm{ml})$. The results are obtained from pre-type II alveolar epithelial cells isolated from three litters of fetal (day 19 gestation) rats. Statistical analysis was performed using ANOVA. $* P<$ 0.005 between group means.

13). Because LRP is the sole receptor for $\alpha_{2} M^{*}$ clearance, these data establish that type II cells have an active LRP pathway. However, culture of these cells in cholesterol-free medium had no effect on ${ }^{125} \mathrm{I}-\alpha_{2} \mathrm{M}^{*}$ catabolism (Fig. $2 \mathrm{D}$ ) as expected because the LRP pathway is not sterol regulated $(10,13)$.

In addition to the studies on immortalized alveolar pretype II epithelial cells described above, we performed similar experiments in primary cultures of pre-type II cells (Fig. 3). These experiments confirmed the ability of the cells to take up and degrade VLDL and LDL in a sterol-regulated manner (data not shown). VLDL degradation was enhanced by the addition of either LPL or GST-LPLC, and partially inhibited by RAP (Fig. 3). Effects of LPL on ${ }^{125}$ I-VLDL surface binding and uptake were similar to its effects on degradation (data not shown). Due to the more limited availability of primary pretype II cells, most experiments were performed using the immortalized cell line.

Effect of VLDL on de novo synthesis of fatty acids. The studies above using ${ }^{125}$ I-labeled ligands confirmed the presence of intact LDL receptor and LRP pathways in pre-type II cells. We next focused on the effects of lipoproteins on fatty acid and surfactant phospholipid synthesis. Incubation of immortalized cells with VLDL for 4 or $24 \mathrm{~h}$ led to a significant decrease in the biosynthesis of fatty acids (Fig. 4). We selected these time points since it has been previously shown that de novo fatty synthesis is subject to both short- and long-term regulation (44). The rates of incorporation of ${ }^{3} \mathrm{H}_{2} \mathrm{O}$ into total saponifiable fatty acids were highest in cells incubated in LPDS. After a 4-h incubation with VLDL alone, the rates of incorporation of ${ }^{3} \mathrm{H}_{2} \mathrm{O}$ into fatty acids decreased by two thirds compared with cells cultured in LPDS with or without LPL $(P<0.005)$. Moreover, cells exposed to both VLDL and LPL exhibited an over fourfold reduction in fatty acid production compared with similar controls $(P<0.001)$. As shown in Fig. 4 , similar effects were observed on de novo fatty acid synthesis rates after 24-h incubations with VLDL $(P<0.001$ vs. LPL) or in the presence of VLDL and LPL $(P<0.05$ vs. FCS $)$. These results suggest that pre-type II cells compensate for the increased fatty acid delivery from VLDL by decreasing endogenous fatty acid synthesis. 


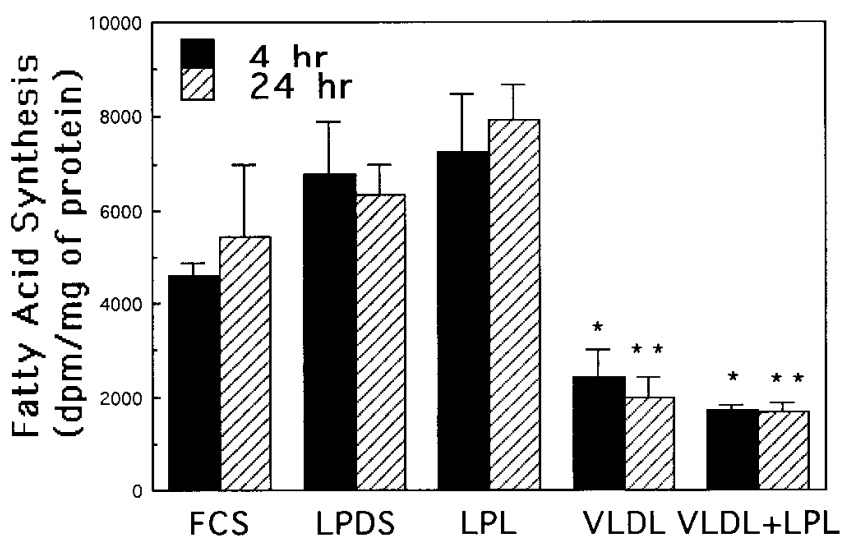

Figure 4. Effect of VLDL on de novo synthesis of fatty acids. Immortalized alveolar pre-type II cells were incubated in Waymouth's medium containing either $10 \%$ FCS or LPDS in the presence of VLDL $(30 \mu \mathrm{g} / \mathrm{ml})$, LPL $(0.5 \mu \mathrm{g} / \mathrm{ml})$, or VLDL $(30 \mu \mathrm{g} / \mathrm{ml})$ plus LPL $(0.5 \mu \mathrm{g} / \mathrm{ml})$ for 4 or $24 \mathrm{~h}$ as indicated. The LPL was added only during the last $2 \mathrm{~h}$ of incubation. Total saponifiable fatty acids in cells were measured by labeling cells with $5 \mathrm{mCi} /$ dish of $\left[{ }^{3} \mathrm{H}\right] \mathrm{H}_{2} \mathrm{O}$ during the final $4 \mathrm{~h}$ of incubation. The cellular lipids were saponified, the fatty acids extracted and separated using thin-layer chromatography, and specific activity expressed as disintegrations per minute per milligram protein. The values are expressed as the mean \pm SEM and are representative of three separate experiments. Statistical analysis was performed using ANOVA. $* P<0.005$ vs. LPDS and LPL groups. $* * \mathrm{P}<0.001$ vs. LPL group and $P<0.05$ vs. FCS and LPDS groups at $24 \mathrm{~h}$.

Effect of VLDL on phosphatidylcholine synthesis. In contrast with the suppression of fatty acid synthesis by LPL-stimulated VLDL uptake, incubation of immortalized cells with VLDL in the presence of LPL produced a significant increase in the rate of choline incorporation into PC (Fig. 5). We compared the short-term effects of VLDL and LPL on choline incorporation into $\mathrm{PC}$ in immortalized cells with primary isolates of fetal alveolar type II epithelial cells (Fig. 5, $A$ and $B$ ). Compared with control conditions, VLDL and LPL increased activity twofold in immortalized cells cultured in the presence of FCS or LPDS. Exposure of these cells to VLDL or LPL alone did not increase choline incorporation into PC (Fig. $5 A$ ). In separate studies using immortalized cells, long-term $(24 \mathrm{~h})$ exposure to VLDL and LPL increased choline incorporation into PC and DSPC by 136 and 59\%, respectively, above the levels achieved when cells were cultured with FCS or LPDS alone $(P<0.001$, data not shown $)$.

As seen with immortalized pre-type II cells, incubation of freshly isolated pre-type II cells with VLDL and LPL either in FCS or LPDS for $4 \mathrm{~h}$ stimulated choline incorporation into PC nearly fourfold compared with control (Fig. 5 B). Compared with cells cultured in FCS, these primary isolates also had modestly increased basal rates of choline incorporation when cultured in LPDS alone, with or without the addition of LPL or VLDL. In the presence of exogenous LPL, VLDL increased by $60 \%$ the incorporation of $\left[{ }^{3} \mathrm{H}\right]$ choline into DSPC (data not shown). These results suggest that both immortalized and primary pre-type II cells increase surfactant production to a similiar degree in the presence of VLDL and LPL, and that upregulation of the LDL receptor pathway had no or only a small effect under the conditions used here.
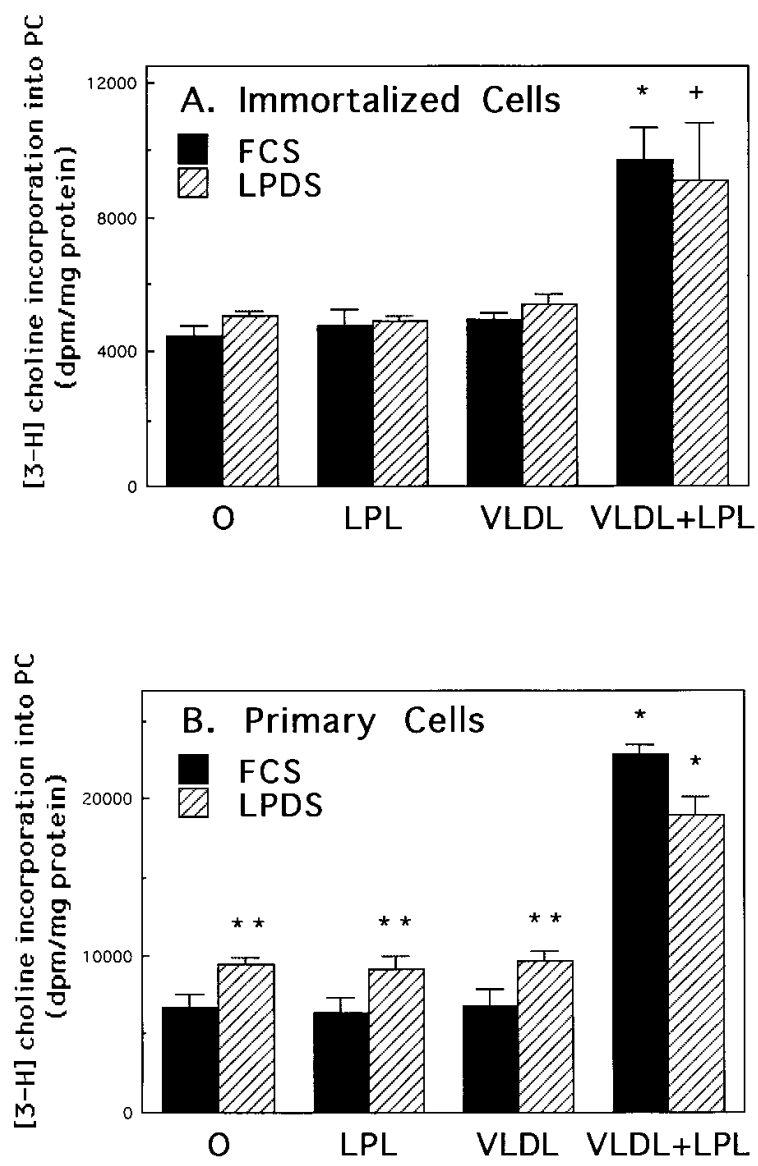

Figure 5. Effect of VLDL on choline incorporation into phosphatidylcholine in alveolar pre-type II epithelial cells. $(A)$ Immortalized cells and $(B)$ primary isolates of pre-type II cells were plated and cultured overnight in Waymouth's medium containing either $10 \%$ FCS or LPDS. The cells were then incubated for $4 \mathrm{~h}$ either in medium alone or with the same medium plus VLDL ( $30 \mu \mathrm{g} / \mathrm{ml})$, LPL $(0.5 \mu \mathrm{g} / \mathrm{ml})$, or VLDL $(30 \mu \mathrm{g} / \mathrm{ml})$ plus LPL $(0.5 \mu \mathrm{g} / \mathrm{ml})$. The LPL was added only during the last $2 \mathrm{~h}$ of incubation. The rates of choline incorporation into PC in cells were measured as described in Methods. The values are expressed as disintegrations per minute per milligram protein and as the mean \pm SEM. The data is representative of three separate experiments. Statistical analysis was performed using ANOVA. $* P<0.001$ VLDL plus LPL vs. the 0 , LPL, and VLDL groups. ${ }^{+} P<0.05$ VLDL plus LPL vs. the 0 , LPL, and VLDL groups. $* * P<0.05$ in LPDS vs. a similiar group in FCS.

Cytidylyltransferase activity. Exposure of immortalized pretype II cells to VLDL and LPL stimulated PC production by increasing the activity of $\mathrm{CT}$, the rate-limiting enzyme for PC synthesis. In preliminary studies, we observed that activation of the enzyme by VLDL was dose dependent, with highest activities detected when cells were exposed to $30-40 \mu \mathrm{g} / \mathrm{ml}$ of lipoprotein (data not shown). Subsequently, time-course studies revealed that cells cultured in FCS or LPDS in the presence or absence of LPL alone exhibited relatively low levels of CT activity that did not fluctuate greatly over the entire incubation period (1-24 h, Fig. $6 A$ ). Cells exposed to VLDL alone tended to have higher levels of CT activity over time in culture. As expected from the data presented above, the combination of LPL and VLDL in the culture medium produced a substantial 

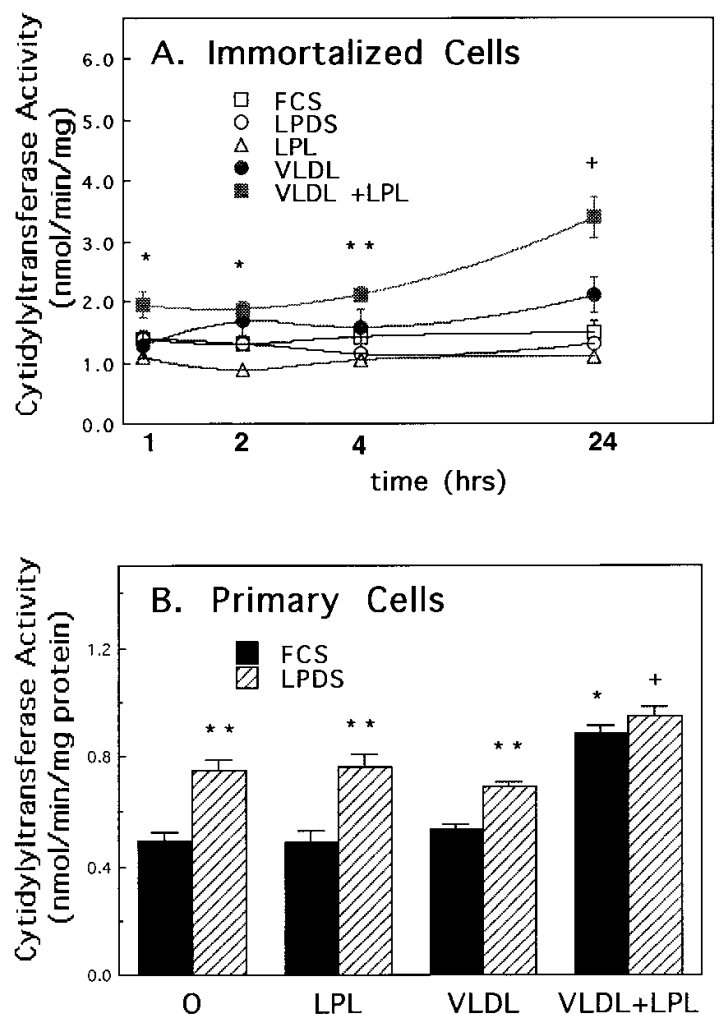

Figure 6. Effects of VLDL on cytidylyltransferase activity in alveolar pre-type II epithelial cells. ( $A$ ) Time-dependent effects in immortalized cells were determined by incubating cells in Waymouth's medium containing FCS, LPDS, or medium with LPDS in the presence of VLDL $(30 \mu \mathrm{g} / \mathrm{ml})$, LPL $(0.5 \mu \mathrm{g} / \mathrm{ml})$, or VLDL $(30 \mu \mathrm{g} / \mathrm{ml})$ plus LPL $(0.5 \mu \mathrm{g} / \mathrm{ml})$ for various time periods. CT activity was assayed in total cell lysates in the absence of lipid activator in the assay mixture. (B) Effects of VLDL on CT activity in primary isolates of pre-type II cells was determined under conditions described in Fig. 5. CT activity is expressed as nanomoles per minute per milligram of cell protein. The data are expressed as the mean \pm SEM. Each data point is representative of three separate experiments. Statistical analysis was performed using ANOVA. $(A) * P<0.05$ vs. the LPL group. $* * P<0.05$ vs. the LPDS and LPL groups. ${ }^{+} P<0.005$ vs. the FCS, LPDS, and LPL groups. $(B) * P<0.001$ VLDL plus LPL vs. the 0 , LPL, and VLDL groups. ${ }^{+} P<0.02$ VLDL plus LPL vs. the 0 , LPL, and VLDL groups. $* * P<0.01$ in LPDS vs. a similiar group in FCS.

increase in CT activity. At 1 and 2 h, VLDL with LPL stimulated CT activity by 78 and $116 \%$, respectively, above control cultures $(P<0.05$ vs. LPL group, Fig. $6 A)$. This effect was even more pronounced at 4 and $24 \mathrm{~h}$ when VLDL and LPL activated the enzyme by threefold compared with the LPL group $(P<0.001)$. Additional studies revealed that $\mathrm{CT}$ activation by VLDL and LPL was associated with redistribution of enzyme activity from the cytosolic to the microsomal subcellular fraction as expected based upon our current understanding of the mechanism of CT activation (45). Incubation of cells with VLDL and LPL for $24 \mathrm{~h}$ decreased cytosolic activity $~ 38 \%$ compared with control conditions, and this was associated with a twofold increase in microsomal activity $(P<0.001$, data not shown). Similar to the results in immortalized cells, VLDL and LPL increased CT activity in primary isolates of fetal alveolar type II epithelial cells (Fig. $6 B$ ). However, the culture of cells
A)

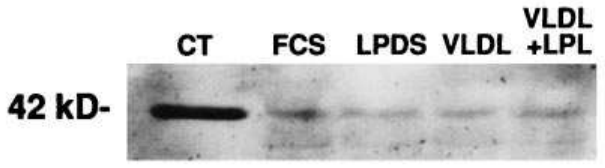

B)

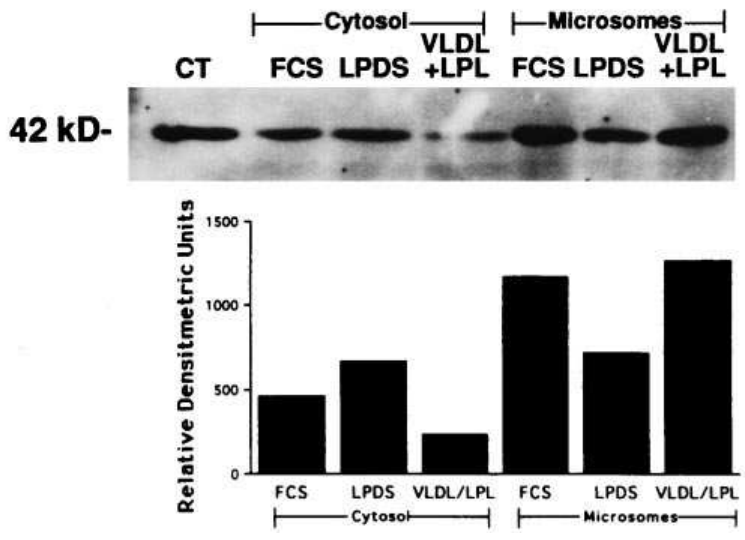

Figure 7. Effect of VLDL and LPL on the levels of immunoreactive CT. Immortalized pre-type II cells were incubated in Waymouth's medium containing FCS, LPDS, or medium with LPDS in the presence of VLDL $(30 \mu \mathrm{g} / \mathrm{ml})$, or VLDL $(30 \mu \mathrm{g} / \mathrm{ml})$ plus LPL $(0.5 \mu \mathrm{g} / \mathrm{ml})$ for $24 \mathrm{~h}$. $(A)$ The amount of CT was assayed in total cell lysates by Western blotting. (Left lane) Purified CT from rat liver $(10 \mu \mathrm{g})$. (Right lanes) Cells exposed to FCS, LPDS, VLDL, or VLDL plus LPL. Lanes were loaded with equal amounts of cellular protein $(300 \mu \mathrm{g}) .(B)$ The levels of immunoreactive CT were assayed in the cytosolic and microsomal preparations. The left lane represents CT standard $(10 \mu \mathrm{g})$. Each lane was loaded with equal amounts of cytosolic or microsomal protein $(400 \mu \mathrm{g})$. (Bottom) Densitometric analysis of the autoradiograms was performed. The results are representative of three separate experiments.

in LPDS stimulated basal CT activity consistent with results in Fig. $5 B$.

Immunodetection of $C T$. Western blotting of cell lysates from immortalized cells was performed to determine if the lipoproteins increased CT activity by increasing the amount of enzyme. The levels of total cellular immunoreactive enzyme in lysates remained unchanged after treatment of cells with VLDL either in the presence or absence of LPL (Fig. $7 A$ ). Analysis performed on subcellular preparations revealed that the majority of enzyme mass in cells treated with FCS, LPDS, or VLDL plus LPL was detected in the microsomes, consistent with the subcellular distribution of CT activity as discussed above. Cells treated with VLDL and LPL contained significantly lower levels of cytosolic CT mass compared with either the FCS- or LPDS-treated cells (Fig. 7 B). VLDL and LPL addition to cells resulted in a substantial increase in the amount of immunoreactive CT in the microsomal extracts compared with controls. Densitometric analysis of the immunoblots confirmed that a greater proportion of the enzyme mass was detected in microsomes after VLDL and LPL treatment (Fig. $7 B$, bottom). Thus, these results suggest that LPL induced cellular uptake of VLDL-activated CT by promoting the association of the enzyme with the intracellular membrane.

Effect of VLDL and LPL variants on cytidylyltransferase activation. It has been shown that LPL contains catalytic, re- 


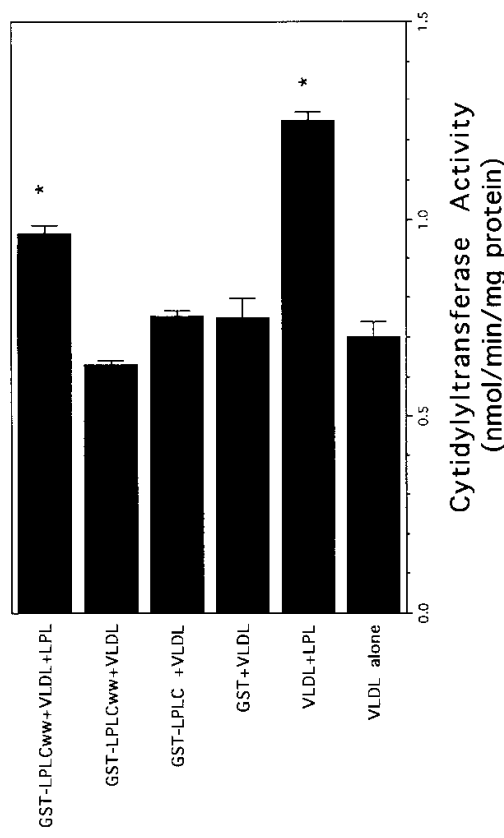

Figure 8. Effect of VLDL, GST-LPL, or GST-LPLCww on cytidylyltransferase activation. Immortalized pre-type II cells were incubated in Waymouth's medium containing LPDS alone or in the presence of various combinations of LPL $(0.5 \mu \mathrm{g} / \mathrm{ml})$, VLDL $(30 \mu \mathrm{g} / \mathrm{ml})$, GST $(100 \mu \mathrm{g} / \mathrm{ml})$, GST-LPLC $(15 \mu \mathrm{g} / \mathrm{ml})$, or GSTLPLCww $(100 \mu \mathrm{g} / \mathrm{ml})$ for $4 \mathrm{~h}$. CT activity was assayed in total cell lysates in the absence of lipid activator in the assay mixture. The data are expressed as the mean \pm SEM. Each data point is represen-

tative of three separate experiments. Statistical analysis was performed using ANOVA. $* P<0.01$ vs. all groups.

ceptor-binding, and lipoprotein-binding domains (8, 11-13). Therefore, we compared the effects of native LPL with GSTLPLC. We also studied the LPLC variant, GST-LPLCww. Consistent with earlier data, immortalized pre-type II cells exposed to VLDL and LPL stimulated CT activity twofold over control (see Figs. 6 and 8). GST-LPLC, GST-LPLCww, or GST did not stimulate CT activity in the presence of VLDL. In control experiments, immortalized cells exposed to LPL, GSTLPLC, GST-LPLCww, or GST alone did not increase CT activity above control values (data not shown). GST-LPLCww inhibited CT activation by native LPL and VLDL by $21 \%$ (Fig. 8).

\section{Discussion}

Long-chain fatty acids serve two integral roles in surfactant lipid synthesis: first as substrates used in the biosynthesis of phospholipids and, second, as activators of key enzymes involved in PC synthesis (46). Depending on the stage of lung development, the major source of lung fatty acids used for these purposes may be derived either from plasma fatty acids or endogenous synthesis $(6,46)$. Although interest in the potential role of fatty acids derived from circulating triglyceriderich lipoproteins such as VLDL in regulating surfactant metabolism originated nearly $20 \mathrm{yr}$ ago (18), to date there has been a paucity of data that addresses this issue. Earlier studies by Compton et al. using an isolated perfused rat lung system reported that $\left[{ }^{14} \mathrm{C}\right]$ tripalmitin is incorporated into lung phospholipids (47). Using a similar approach, Hass and Longmore reported that $\left[{ }^{3} \mathrm{H}\right]$ cholesterol contained in LDL preparations became incorporated into surfactant when added to the medium of perfused rat lungs $(48,49)$. In addition, a recent study also demonstrated that LDL stimulates surfactant secretion in adult type II cells in vitro, and that these effects were temporally associated with activation of phosphatidylinositol turn- over (50). The present study, however, represents the first demonstration that lipoproteins stimulate surfactant synthesis through interactions with LPL and to a lesser degree with cell surface lipoprotein receptors.

To investigate the role of VLDL in vitro, we performed studies using an immortalized fetal alveolar pre-type II epithelial cell line and primary isolates of pre-type II cells $(35,36)$. The immortalized cell line was used both because of the limited availability of primary cells and their progressive loss of differentiated functions (e.g., PC synthesis) within hours after culture (51). This was of special concern in the present investigations because, unlike the rapid effects of LDL on surfactant secretion (50), VLDL effects on PC synthesis only became maximal after 24-h incubations. The cell line we used displays a number of characteristics of immature alveolar type II epithelial cells, including a relatively low activity of CT compared with more mature alveolar type II epithelial cells (Mallampalli, unpublished data). In addition, we previously established that they express gp330/LRP2, a receptor for LPL and VLDL that also serves in the endocytic clearance of at least two fibrinolytic proteases (14). Such proteases may be responsible for the cleavage of proteins that are inhibitory for surfactant function (52).

Radiolabeled ligand experiments demonstrate that both immortalized cells and primary isolates of pre-type II cells effectively surface bind, internalize, and degrade VLDL, and that these effects are induced severalfold by the inclusion of LPL in the culture medium (Fig. 1). LPL has little effect on LDL catabolism, as might be expected because LDL is a poor substrate for this enzyme. Because of its heparin-binding properties, it is likely that LPL promotes the internalization of VLDL by binding first to cell surface-associated proteoglycans, which facilitate diffusion of LPL-VLDL complexes along the cell surface until they encounter a lipoprotein receptor that mediates internalization and degradation of the complexes (7, 8). During this process, active lipolysis of the VLDL will release free fatty acids and perhaps also expose sites on apoE and apoB100 that recognize receptors. This scenario has been described in other in vitro systems $(8,53)$.

Available data indicates that alveolar type II epithelial cells express three members of the LDL receptor family. VoynoYasenetskaya et al. (50) and the current studies indicate that LDL receptors are present in fetal and adult type II cells. Data in Fig. 2 establish that LRP actively mediates $\alpha_{2} \mathrm{M}^{*}$ catabolism in pre-type II epithelial cells, and our previous work established that gp330/LRP-2 is present and functional (14). Of these, gp330/LRP-2 is of particular interest due to its restricted expression by type II cells and certain other specialized epithelia. Willnow et al. observed that homozygous gp330/LRP-2 knockout mice die shortly after birth from respiratory failure associated with severe atelectasis and emphysema (54). Unlike LDL receptors, both LRP and gp330/LRP-2 have been implicated in the clearance of certain proteases and fibrinolytic factors that may be important in the lung. However, all three receptors bind LPL-VLDL complexes and may provide redundant mechanisms for lipid uptake by alveolar pre-type II epithelial cells. The current studies do not completely distinguish the relative contributions of each receptor type to VLDL uptake and catabolism. However, the fact that RAP, a selective antagonist for all members of the $\operatorname{LDL}$ family $(8,13,14$, 16), partially blocks this process establishes a role for these receptors in VLDL catabolism in pre-type II cells. The observation that GST-LPLCww inhibits VLDL degradation both in 
the presence and absence of LDL receptor upregulation (Fig. $2 C$ ) and blocks $\alpha_{2} \mathrm{M}^{*}$ catabolism (Fig. $2 \mathrm{D}$ ) further indicates that GST-LPLCww inhibits both the LDL receptor and LRP pathways. The activity of the gp330/LRP-2 pathway was not specifically assessed but likely was also inhibited by GSTLPLCww as suggested by the data in Fig. $2 C$.

Delivery of VLDL triglycerides to pre-type II cells has opposite effects on fatty acid and PC synthesis. Exposure of lipoproteins to pre-type II cells produces a substantial decrease in de novo fatty acid synthesis. Cells incubated in the presence of LPDS tend to exhibit the highest rates of incorporation of ${ }^{3} \mathrm{H}_{2} \mathrm{O}$ into total fatty acids, whereas cells cultured in the presence of VLDL express the lowest rates of activity. These changes may represent a compensatory response to the availability of exogenous fatty acids. In contrast to de novo fatty acid synthesis, incubation of cells with VLDL leads to a significant increase in PC and DSPC synthesis. Phosphatidylcholine synthesis is stimulated by the inclusion of LPL in the culture medium after both short (i.e., 4 h, Fig. 5) and long (24 h) term incubation (data not shown). The effects on DSPC synthesis are significant because they represent a more reliable indicator of surfactant production. VLDL alone does not appear to significantly alter PC production, suggesting that LPL must be present for the fatty acid products of lipolysis to be released from triglycerides, gain cellular entry, and subsequently become available in sufficient quantities for PC biosynthesis. On the other hand, VLDL alone suppresses de novo fatty acid synthesis because even in the absence of LPL some of the lipoprotein is internalized and degraded within lysosomes (Fig. 1). Presumably, the released fatty acid can then regulate endogenous fatty acid metabolism, but it is used by the cell for purposes other than PC synthesis.

To further investigate the mechanisms by which VLDL facilitates delivery of fatty acids to CT, we performed studies using GST-LPLC, a catalytically inactive carboxy-terminal domain of LPL that retains the ability to bind lipoprotein receptors and promote cellular uptake and degradation of VLDL (12). Studies were also done using a variant of LPLC that lacks the ability to bind VLDL (GST-LPLCww). GST-LPLCww is an antagonist of receptor-mediated catabolism via the LDL receptor or LRP pathways (11-13). Compared with native LPL, exposure of cells to VLDL with GST-LPLC did not result in enzyme activation, despite inducing VLDL uptake and degradation to a comparable degree (Fig. $2 A$ ). This suggests that active lipolysis of VLDL is required for enzyme activation under the conditions used here. Moreover, the receptor antagonist GST-LPLCww decreased CT activation by only $21 \%$, despite $>90 \%$ inhibition of VLDL degradation (Figs. $2 B$ and 8), further suggesting that active extracellular lipolysis is more important than intracellular VLDL degradation as a means to activate CT.

Culture of pre-type II cells with VLDL produced a substantial increase in CT activity, thus activating the rate-limiting step for PC synthesis. There are several mechanisms by which VLDL might stimulate CT activity in these studies, including CT activation by reversible phosphorylation (55), membrane translocation (45), enhanced gene expression (56), and regulation by a variety of lipids $(38,40,57,58)$. It is possible that the increase in enzyme activity is due to cholesterol esters carried in VLDL since cholesterol has been demonstrated to increase PC synthesis in various systems (57). However, cholesterol ester comprises only 10-15\% of VLDL lipid (7), and exposure of pre-type II cells to LDL in the presence of LPL does not produce similar degrees of uptake (Fig. 1) or of enzyme activation (data not shown), making this mechanism a less likely possibility. We interpret our results as suggesting that CT activity is stimulated by the presentation of exogenous fatty activators to the enzyme that result from hydrolysis of VLDL triglyceride by the actions of LPL. Perhaps equally important, it is likely that an even greater stimulation on CT activity by these products of lipolysis would have occurred if there was not a concurrent downregulation of endogenous fatty acid synthesis (Fig. 4). We found direct evidence to support a membrane translocation mechanism for CT activation by lipoproteins. However, we have not excluded the possibility that the fatty acids released during lipolysis of VLDL enter the cytosol, where they might promote the dephosphorylation and relocation of CT to the membrane where the enzyme might be further activated by anionic phospholipids $(55,58)$.

These results can be contrasted with recent studies suggesting that primary isolates of alveolar pre-type II epithelial cells, unlike fibroblasts, cannot directly incorporate triglycerides from the culture medium (26). Our observations suggest that lipid uptake occurs when the neutral lipids are carried by lipoprotein particles that are recognized and internalized by alveolar pre-type II epithelial cells. Alternatively, the intact VLDL particle can undergo LPL-mediated hydrolysis while anchored to cell surface proteoglycans. Both mechansims will generate fatty acid substrates to be used by cells. Only limited stimulation of surfactant production occurs in the absence of LPL's hydrolytic activity. The previously reported ability of triglyceride-loaded lung interstitial fibroblasts to stimulate surfactant synthesis in pre-type II cells (26) represents a third mechanism whereby circulating triglycerides could stimulate surfactant synthesis. Studies in vivo are needed to determine if these mechanisms are complementary under conditions where there is a high demand for surfactant production. In addition, alveolar macrophages may participate in lipid uptake for surfactant production by secretion of LPL either into interstitial or alveolar fluid $(23,24)$. Because lipoprotein transport into bronchoalveolar lavage fluid is poorly understood, the physiological relevance of LPL-induced apical catabolism of lipoproteins by alveolar pre-type II epithelial cells remains to be established.

In summary, our studies demonstrate that surfactant phospholipid synthesis is stimulated by VLDL. Lipolysis of these particles by the action of LPL greatly potentiates the effects of VLDL on PC synthesis and CT activity. Future studies will need to address several important issues in this area, including the specific determinants for maximal lipolysis at the alveolar cell surface, how the lipolysis products (e.g., fatty acid and monoacylglycerol) are transferred and made directly available to CT for surfactant synthesis, and the potential role of VLDL-associated apoproteins (e.g., apoB-100, apoC, apoE) and VLDL remnant particles on surfactant metabolism. Such investigations may ultimately help determine appropriate clinical management of some pulmonary diseases. For example, it is possible that administration of these lipoproteins in vivo might attenuate functional surfactant deficiencies observed in a variety of lung disorders.

\section{Acknowledgments}

This study was supported by the Office of Research and Development, the Department of Veteran's Affairs (VA), National Institutes of 
Health (NIH) grant HL-55584, a Grant-In-Aid from the American Heart Association, and the Children's Miracle Network (to R.K. Mallampalli), and NIH grant HL-49264 (to D.A. Chappell).

\section{References}

1. Rooney, S.A. 1985. State of art: the surfactant system and lung phospholipid biochemistry. Am. Rev. Resp. Dis. 131:439-460.

2. Spragg, R.G., N. Gillard, P. Richman, R.M. Smith, D. Hite, D. Pappert, B. Robertson, T. Curstedt, and D. Strayer. 1994. Acute effects of a single dose of porcine surfactant on patients with the adult respiratory distress syndrome. Chest. 105:195-202.

3. Robinson, P.C., L.C. Watters, T.E. King, and R.J. Mason. 1988. Idiopathic pulmonary fibrosis. Abnormalities of bronchoalveolar lavage fluid phospholipids. Am. Rev. Respir. Dis. 137:585-591.

4. Kurashima, K., H. Ogawa, T. Ohka, M. Fugimura, T. Matsuda, and T. Kobayashi. 1991. A pilot study of surfactant inhalation in the treatment of asthmatic attack. Jpn. J. Allergol. 40:160-163.

5. Lusardi, M., A. Capelli, S. Carli, M. Salmona, and C.F. Donner. 1992. Role of surfactant in chronic obstructive pulmonary disease: therapeutic implications. Respiration. 59:28-32.

6. Batenburg, J.J. 1992. Surfactant phospholipids: synthesis and storage. Am. J. Physiol. 262:L367-L385.

7. Fielding, P.F., and C.J. Fielding. 1991. Dynamics of lipoprotein transport in the circulatory system. In Lipids, Lipoproteins, and Biomembranes. D.E. Vance and J. Vance, editors. Elsevier, Amsterdam. 427-450.

8. Chappell, D.A., G.L. Fry, M.A. Waknitz, L.E. Muhonen, M.W. Pladet, P.H. Iverius, and D.K. Strickland. 1993. Lipoprotein lipase induces catabolism of normal triglyceride-rich lipoproteins via the low density lipoprotein receptor-related protein/ $/ 2$-macroglobulin receptor in vitro. J. Biol. Chem. 268: $14168-14175$.

9. Chappell, D.A., G.L. Fry, M.A. Waknitz, L.E. Muhonen, and M.W. Pladet. 1993. Low density lipoprotein receptors bind and mediate cellular catabolism of normal very low density lipoproteins in vitro. J. Biol. Chem. 268:2548725493.

10. Strickland, D.K., M.Z. Kounnas, and W.S. Argraves. 1995. LDL receptor-related protein: a multiligand receptor for lipoprotein and proteinase catabolism. FASEB J. 9:890-898.

11. Williams S.E., I. Inoue, H. Tran, G.L. Fry, M.W. Pladet, P.H. Iverius, J.M. Lalouel, D.A. Chappell, and D.K. Strickland. 1994. The carboxyl-terminal domain of lipoprotein lipase binds to the low density lipoprotein receptorrelated protein/ $\alpha 2$-macroglobulin receptor (LRP) and mediates binding of normal very low density lipoproteins to LRP. J. Biol. Chem. 269:8653-8658.

12. Chappell, D.A., I. Inoue, G.L. Fry, M.W. Pladet, S.L. Bowen, P.H. Iverius, J.M. Lalouel, and D.K. Strickland. 1994. Cellular catabolism of normal very low density lipoproteins via the low density lipoprotein receptor-related protein/ $\alpha 2$-macroglobulin receptor is induced by the C-terminal domain of lipoprotein lipase. J. Biol. Chem. 269:18001-18006.

13. Medh, J.D., S.L. Bowen, G.L. Fry, S. Ruben, M. Andracki, I. Inoue, J.M. Lalouel, D.K. Strickland, and D.A. Chappell. 1996. Lipoprotein lipase binds to low-density lipoprotein receptors and induces receptor-mediated catabolism of very low density lipoproteins in vitro. J. Biol. Chem. 271:1707317080 .

14. Stefansson S., M. Kounnas, J. Henkin, R.K. Mallampalli, D.A. Chappell, D.K. Strickland, and W.S. Argraves. 1995. Gp330 on type II pneumocytes mediates endocytosis leading to degradation of pro-urokinase, plasminogen activator inhibitor-1 and urokinase-plasminogen activator inhibitor-1 complex. $J$. Cell Sci. 108:2361-2368.

15. Chatellet, F., E. Brianti, P. Ronco, J. Roland, and P. Verroust. 1986. Ultrastructural localization by monoclonal antibodies of brush border antigens expressed by glomeruli. II. Extrarenal distribution. Am. J. Pathol. 122:512-519.

16. Kounnas, M.Z., D.A. Chappell, D.K. Strickland, and W.S. Argraves. 1993. Glycoprotein 330, a member of the low density lipoprotein receptor family, binds lipoprotein lipase in vitro. J. Biol. Chem. 268:14176-14181.

17. Child, G.V., W.M. Thurlbeck, and B.I. Weigensberg. 1974. Severe pulmonary atherosclerosis in hypercholesteremic rabbits. Arch. Pathol. 98:47-50.

18. Hamosh, M., M.R. Simon, H. Canter, Jr., and P. Hamosh. 1978. Lipoprotein lipase activity and blood triglyceride levels in fetal and newborn rats. Pediatr. Res. 12:1132-1136.

19. Pietra, G.G., L.G. Spagnoli, D.M. Capuzzi, C.E. Sparks, A.P. Fishman, and J.B. Marsh. 1976. Metabolism of ${ }^{125} \mathrm{I}$-labeled lipoproteins by the isolated rat lung. J. Cell Biol. 70:33-46.

20. Sparks, C.E., J.L. Dehoff, D.M. Capuzzi, G. Pietra, and J.B. Marsh. 1978. Proteolysis of very low density lipoprotein in perfused lung. Biochim. Biophys. Acta. 529:123-130.

21. Gal, S., D.J.P. Bassett, M. Hamosh, and P. Hamosh. 1982. Triacylglycerol hydrolysis in the isolated, perfused rat lung. Biochim. Biophys. Acta. 713: $222-229$

22. Compton, S.K., M. Hamosh, and P. Hamosh. 1982. Hydrolysis of triglycerides in the isolated perfused rat lung. Lipids. 17:676-702.
23. Mahoney, E.M., J.C. Khoo, and D. Steinberg. 1982. Lipoprotein lipase secretion by human monocytes and rabbit alveolar macrophages in culture. Proc. Natl. Acad. Sci. USA. 79:1639-1642.

24. Okabe, T., H. Yorifugi, T. Murase, and F. Takaku. 1984. Pulmonary macrophage: a major source of lipoprotein lipase in the lung. Biochem. Biophys. Res. Commun. 125:273-278.

25. Maksvytis, H.J., R.M. Niles, L. Simanovsky, I.A. Minassian, L.L. Richardson, M. Hamosh, P. Hamosh, and J.S. Brody. 1984. In vitro characteristics of the lipid-filled interstitial cell associated with postnatal lung growth: evidence for fibroblast heterogeneity. J. Cell Physiol. 118:113-123.

26. Torday, J., J. Hua, and R. Slavin. 1995. Metabolism and fate of neutral lipids of fetal lung fibroblast origin. Biochim. Biophys. Acta. 1254:198-206.

27. Henning, B., D.M. Shasby, and A.A. Spector. 1985. Exposure to fatty acid increases human low density lipoprotein transfer across cultured endothelial cell monolayers. Circ. Res. 57:776-780.

28. Rapp, J.H., A. Lespine, R.L. Hamilton, N. Colyvas, A.H. Chaumeton, J. Tweedie-Hardman, L. Kotite, S.T. Kunitake, R.J. Havel, and J.P. Kane. 1994 Triglyceride-rich lipoproteins isolated by selected affinity anti-apolipoprotein B immunoabsorption from human atherosclerotic plaques. Arterioscler. Thromb. 14:1767-1774

29. Chung, B.H., G. Tallis, V. Yalamoori, G.M. Anantharamaiah, and J.P. Segrest. 1994. Liposome-like particles isolated from human atherosclerotic plaques are structurally and compositionally similar to surface remnants of triglyceride-rich lipoproteins. Arterioscler. Thromb. 14:622-635.

30. Coonrod, J.D., P. Karathanasis, and R. Lin. 1989. Lipoprotein lipase: a source of free fatty acids in bronchoalveolar lining fluid. J. Lab. Clin. Med. 113: 449-457.

31. Blanchette-Mackie, E.J., M.G. Wetzel, S.S. Chernick, J.R. Paterniti, W.V. Brown, and R.O. Scow. 1986. Effect of the combined lipase deficiency mutation (cld/cld) on ultrastructure of tissues in mice. Lab. Invest. 55:347-362.

32. Post, M., J.J. Batenburg, B.T. Smith, and L.M.G. Van Golde. 1984. Pool sizes of precursors for phosphatidylcholine formation in adult rat lung type II cells. Biochim. Biophys. Acta. 795:552-557.

33. Iverius, P.H., and A.M. Ostlund-Lindqvist. 1976. Lipoprotein lipase from bovine milk. Isolation procedure, chemical characterization, and molecular weight analysis. J. Biol. Chem. 251:7791-7795.

34. Jamil, H., A.K. Utal, and D.E. Vance. 1992. Evidence that cyclic AMPinduced inhibition of phosphatidylcholine biosynthesis is caused by a decrease in cellular diacylglycerol levels in cultured rat hepatocytes. J. Biol. Chem. 267: $1752-1760$.

35. Mallampalli, R.K., C.S. Floerchinger, and G.W. Hunninghake. 1992. Isolation and immortalization of rat pre-type II cell lines. In Vitro Cell. Dev. Biol. 28A:181-187.

36. Post, M., and B.T. Smith. 1988. Histochemical and immunocytochemical identification of alveolar type II epithelial cells isolated from fetal rat lung. Am. Rev. Respir. Dis. 137:525-530.

37. Mallampalli, R.K., M.E. Walter, M.W. Peterson, and G.W. Hunninghake. 1994. Betamethasone activation of CTP:cholinephosphate cytidylyltransferase is lipid dependent. Am. J. Respir. Cell Mol. Biol. 10:48-57.

38. Mallampalli, R.K., C.H. Li, M. Van Rollins, R.G. Salome, and G.W. Hunninghake. 1995. Betamethasone activation of CTP:cholinephosphate cytidylyltransferase is mediated by fatty acids. J. Cell Physiol. 162:410-421.

39. Bligh, E.G., and W.J. Dyer. 1959. A rapid method of total lipid extraction and purification. Can. J. Biochem. Physiol. 37:911-917.

40. Mallampalli, R.K., R.G. Salome, and A.A. Spector. 1994. Regulation of CTP:cholinephosphate cytidylyltransferase by polyunsaturated N-3 fatty acids. Am. J. Physiol. 267:L641-L648.

41. Bradford, M. 1976. A rapid and sensitive method for the quantitation of microgram quantities of protein utilizing the principle of protein-dye binding. Anal. Biochem. 72:248-254.

42. Rosner, B. 1995. Fundamentals of Biostatistics. Wadsworth Publishing Co., Belmont, CA. 314-318.

43. Innerarity, T.L., R.E. Pitas, and R.W. Mahley. 1980. Disparities in the interaction of rat and human lipoproteins with cultured rat fibroblasts and smooth muscle cells. Requirements for homology for receptor binding activity. J. Biol. Chem. 255:11163-11172.

44. Patterson, C.E., K.S. Davis, and R.A. Rhodes. 1988. Regulation of fetal lung disaturated phosphatidylcholine synthesis by de novo palmitate supply. Biochim. Biophys. Acta. 958:60-69.

45. Pelech, S.L., P.H. Pritchard, D.N. Brindley, and D.E. Vance. 1983. Fatty acids promote translocation of CTP:phosphocholine cytidylyltransferase to the endoplasmic reticulum and stimulate rat hepatic phosphatidylcholine synthesis. J. Biol. Chem. 258:6782-6788.

46. Rooney, S.A. 1989. Fatty acid biosynthesis in developing fetal lung. Am. J. Physiol. 257:L195-L201.

47. Compton, S.K., M. Hamosh, and P. Hamosh. 1984. Hydrolysis of neutral lipids and phospholipids in the isolated, perfused rat lung. Biochim. Biophys. Acta. 795:30-36.

48. Hass, M.A., and W.J. Longmore. 1979. Surfactant cholesterol metabolism of the isolated perfused rat lung. Biochim. Biophys. Acta. 573:166-174.

49. Hass, M.A., and W.J. Longmore. 1980. Regulation of lung surfactant cholesterol metabolism by serum lipoproteins. Lipids. 15:401-406. 
50. Voyno-Yasenetskaya, T.A., L.G. Dobbs, S.K. Erickson, and R.L. Hamilton. 1993. Low density lipoprotein- and high density lipoprotein-mediated signal transduction and exocytosis in alveolar type II cells. Proc. Natl. Acad. Sci. USA. 90:4256-4260.

51. Mason, R.J., and L.G. Dobbs. 1980. Synthesis of phosphatidylcholine and phosphatidylglycerol by alveolar type II cells in primary culture. J. Biol. Chem. 255:5101-5107.

52. Seeger, W., C. Grube, and A. Gunther. 1993. Proteolytic cleavage of fibrinogen: amplification of its surfactant inhibitory capacity. Am. J. Respir. Cell Mol. Biol. 9:239-247.

53. Kounnas, M.Z., D.A. Chappell, H. Wong, W.S. Argraves, and D.K. Strickland. 1995. The cellular internalization and degradation of hepatic lipase is mediated by low density lipoprotein receptor-related protein and requires cell surface proteoglycans. J. Biol. Chem. 270:9307-9312.

54. Willnow, T.E., J. Hilpert, S.A. Armstrong, A. Rohlmann, R.E. Ham- mer, D.K. Burns, and J. Herz. 1996. Defective forebrain development in mice lacking gp330/megalin. Proc. Natl. Acad. Sci. USA. 93:8460-8464.

55. Wang, Y., J.I.S. MacDonald, and C. Kent. 1993. Regulation of CTP phosphocholine cytidylyltransferase in HeLa cells. J. Biol. Chem. 268:55125518.

56. Walkey, C.J., C.B. Kalmar, and R.B. Cornell. 1994. Overexpression of rat liver CTP:phosphocholine cytidylyltransferase accelerates phosphatidylcholine synthesis and degradation. J. Biol. Chem. 269:5742-5749.

57. Shiratori, Y., A.K. Okwu, and I. Tabas. 1994. Free cholesterol loading of macrophages stimulates phosphatidylcholine biosynthesis and up-regulation of CTP:phosphocholine cytidylyltransferase. J. Biol. Chem. 269:11337-11348.

58. Feldman, D.A., C.R. Kovac, P.L. Dranginis, and P.A. Weinhold. 1978 The role of phosphatidylglycerol in the activation of CTP:phosphocholine cytidylyltransferase from rat lung. J. Biol. Chem. 253:4980-4986. 